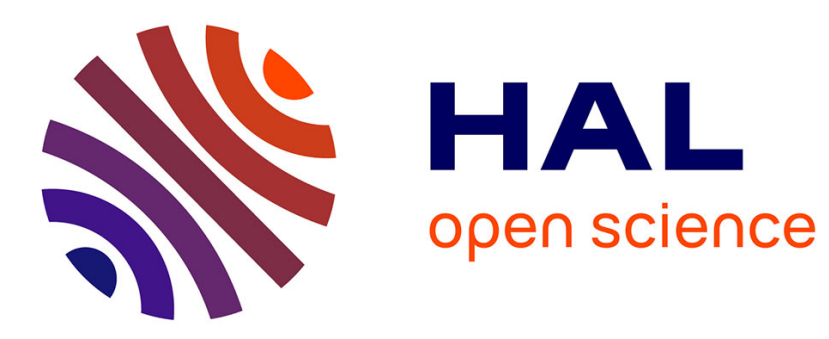

\title{
Trade spillovers on output growth during the 2008 financial crisis
}

Jean-Sébastien Pentecôte, Fabien Rondeau

\section{To cite this version:}

Jean-Sébastien Pentecôte, Fabien Rondeau. Trade spillovers on output growth during the 2008 financial crisis. International Economics, 2015, 143, pp.36-47. 10.1016/j.inteco.2015.04.003 . hal02440549

\section{HAL Id: hal-02440549 \\ https://hal.science/hal-02440549}

Submitted on 15 Jan 2020

HAL is a multi-disciplinary open access archive for the deposit and dissemination of scientific research documents, whether they are published or not. The documents may come from teaching and research institutions in France or abroad, or from public or private research centers.
L'archive ouverte pluridisciplinaire HAL, est destinée au dépôt et à la diffusion de documents scientifiques de niveau recherche, publiés ou non, émanant des établissements d'enseignement et de recherche français ou étrangers, des laboratoires publics ou privés. 


\title{
Trade Spillovers on Output Growth During the 2008 Financial Crisis
}

Jean-Sébastien Pentecôte ${ }^{\mathrm{a}, \mathrm{b}}$, Fabien Rondeau $^{\mathrm{a}, \mathrm{c}}$

${ }^{\mathrm{a}}$ CREM-CNRS, ${ }^{\mathrm{b}}$ University of Caen, ${ }^{\mathrm{c}}$ University of Rennes 1

October 2014

\begin{abstract}
This paper gives an empirical assessment of the extent to which a financial crash in a country can slowdown the domestic economic growth and how these effects can spread through trade relationships. First, we modify the Cerra and Saxena's (2008) methodology in order to understand the interplay between economic activity and foreign trade during the 2008 financial crisis. Our sample is made of monthly data for 26 countries over 1993-2013. We then simulate the dynamic responses of domestic activity to a demand shock and to a financial crisis. Trade contributes to growth in the context of a demand shock (from 63\% for developing countries to $433 \%$ for NAFTA) whereas it dampens output loss in the context of the 2008 financial crisis (from $-38 \%$ for developing countries to $-127 \%$ for NAFTA).
\end{abstract}

Keywords: Global Financial Crisis, Output Loss, Trade Spillovers, Impulse Response Functions

JEL codes: F14, G01, F15

* Corresponding author: Jean-Sébastien Pentecôte, Professor, CREM-CNRS, University of Caen. E-mail: jean-sebastien.pentecote@unicaen.fr.

The authors are grateful to an anonymous referee, Hirokuni Iiboshi, Guillaume L'Oeillet, Sébastien Pommier, Fredj Jawadi and to the participants of the $3^{\text {rd }}$ ISCEF and the $54^{\text {th }}$ conference of the SCSE for helpful comments. 


\section{Introduction}

The Great Financial crisis in 2008 looked to many people as an unprecedented event since World War II given its macroeconomic consequences on the real economy. It led to deep and protracted recessions in many advanced countries coupled with an impressive, though transitory, fall in international trade flows.

According to the NBER business cycle dating for the US economy, the recession lasted eighteen months with a 15 percent decline of the US industrial production $(\mathrm{Ng}$ and Wright, 2013, for an extensive discussion). Moreover, cross-country business cycles were almost fully synchronized around the time of the Great Recession (Imbs, 2010). The recovery of economic activity has been unusually sluggish: only Germany and the US (out of 12 countries having experienced a systemic banking failure) have reached their pre-crisis peaks in terms of per capita income since 2008 (Reinhart and Rogoff, 2009, 2014). The resulting worldwide and severe drop in demand is seen by Baldwin and Taglioni (2009) as primarily responsible for what they termed "the great trade collapse". A major implication is that domestic activity as well as foreign trade may recover rapidly as foreign demand strengthens.

The aim of this article is precisely to analyze the extent to which cross-country trade linkages may have amplified or, instead, mitigated the decline of output caused by the global financial crisis in 2008 . To this end, we study the post-crisis dynamics of real activity on the basis of monthly data on industrial production in 26 countries around the world. These include both developed and emerging countries, some being OECD members whereas the others are not, from January 1993 to June 2013.

In this paper, we try to disentangle trade spillovers during the 2008 financial crisis. According to the literature, trade may dampens or magnify the effects of financial crisis. Following the methodology of Cerra and Saxena (2008), Bussière et al. 
(2012), and Tsangarides (2012), we adopt a dynamic panel data approach. However, measuring the effect of trade spillovers from one country to its partners and vice versa requires extending this framework. Indeed, endogeneity problems may arise here since domestic activity in a given country can be affected by the growth path of its trading partners while, in turn, the latter can be influenced by the financial crisis at home. We thus build impulse response functions of economic activity to various shocks from a dynamic system. It allows assessing the role played by such crossborder trade relationships. We compare the responses of economic activity to a financial crisis shock with those obtained following a fall in real demand. This is done for each of the 26 countries of the sample. Responses at the country level are then aggregated given regional trade or currency agreements.

The article reaches two main conclusions. Firstly, a decline of output caused by negative demand shock is bigger for all 26 counties when bilateral trade relationships are taking into account for than otherwise. In particular, the contraction in industrial production is much larger in countries promoting trade than in those restraining trade, as pointed out by Abeysinghe and Forbes (2005). Secondly, positive trade spillover effects seem to have mitigated the fall in output caused by the global financial crisis for 24 out of 26 countries. This positive effect is consistent with the main findings of Cavallo and Frankel (2008). However, it is uncertain whether the contribution of foreign trade to output dynamics is positive or negative during financial crises.

The rest of the paper is structured as follows. Section 2 gives an overview of the twoway relationship between international trade and banking crises. Section 3 describes our econometric approach and the dataset. Section 4 discusses our main empirical findings. Section 5 concludes. 


\section{Literature review}

\subsection{The effects of financial crises on trade}

Banking crises can affect trade flows through two main channels depending on their effects on the supply-side or on the demand-side.

On the production side, a credit crunch is likely to occur as a consequence of distress and greater reluctance among financial intermediaries in the home economy. This reduces external financing available for the domestic firms. But the credit channel may be more pronounced for the trading sector because, compared with domesticoriented producers, foreign-oriented activities are often subject to greater risks (Love et al., 2007), higher sunk costs of entry (Campa, 2004), and more severe financial constraints (Manova et al., 2011).

On the demand side, the post-crisis economic slump may translate into a collapse in the aggregate demand so that it deters import and/or export flows. To this regard, a given country can suffer from banking crises occurring abroad when they are followed by a substantial decline in import demand from its foreign trading partners. As economic growth slows down in the crisis-hit country, its demand for imports is likely to diminish. By contrast, its exports may either rise or fall depending on whether the banking crisis is twinned with a substantial depreciation or devaluation of the country's currency.

In a long-run perspective, Abiad et al. (2011b) build an augmented gravity model to study the impact of 179 financial crisis episodes over 1970-2009. They conclude that disruptions in financial systems are indeed associated with substantial collapses in imports in the crisis country. Imports are found to persistently fall short of their 
gravity-predicted levels in the years following a financial crisis. Unlike imports, the reduction in exports is rather small in the crisis inception year and it quickly recovers to its pre-crisis level. This result is consistent with the negative influence of the lack of external financing on foreign trade performance when a banking crisis occurs. At the firm level, Amiti and Weinstein (2011) show how the Japanese exporters suffered from a major squeeze in credit by domestic banks during the 1990s. This is consistent with Rajan and Zingales' (1998) argument according to which firms largely dependent on external finance suffer more from a credit squeeze than selffinanced activities. Deleveraging by distressed banks and export-oriented firms may well magnify the impact of troubled financial conditions on international trade flows. Consistently, there is growing empirical evidence pointing to the negative impact that the Great Financial Crisis had on bilateral trade flows. In the advanced economies with well-developed financial systems, the export sector might have been hurt by a big credit crunch as financial firms became illiquid or, worse, insolvent. This is shown by Chor and Manova (2012) who estimate that the increase in the costs of financing from September 2008 to August 2009 may have depressed US imports by as much as 5.5 percent. This is taken as evidence that countries with tighter credit conditions exported less to the US than those free from such problems. In the same vein, Bricongne et al. (2012) find that the exports of French firms being more dependent on external funds were more adversely hit during the recent global crisis. Finally, Berman et al. (2013) found that the fall in trade caused by financial crises is more severe when one accounts for the required delays to ship goods abroad. Because risk of default rises with such delays, this aggregate and firm level evidence point to financial frictions that are exacerbated during a financial crisis. 
In addition, Borensztein and Panizza (2010) highlight the effects of sovereign debt crises on trade flows. They use panel data of 24 countries and 28 industries over the period 1980-2000 and find that export-oriented industries are relatively more affected when a sovereign default occurs. But export firms tend to benefit from real depreciations, thus being less procyclical than domestically-oriented industries.

Abiad et al. (2011a) conclude to incomplete recovery from systemic financial disruptions when output growth is not accompanied with a credit expansion. The persistent lack of external funds is responsible for a weaker and more protracted recovery than it would have been the case otherwise. The robustness of the results from the previous studies can be however questioned since they focus on a relatively short set of financial crises either in a small group of countries or over a narrow time period. On this ground, Cerra and Saxena (2008) have attempted an exhaustive of economic recoveries in a large set of 190 countries and given various financial and/or political crises over 1960-2001. They estimate a dynamic panel data model in order to build various sets of impulse response functions (IRF) of output growth to a set of financial and political shocks. The impulse response functions reveal that situations of financial stress may have persistent negative effects on output. The long-run loss of GDP is the highest in the event of a systemic banking crisis (4 per cent) or twined currency and banking collapses (up to 5 per cent on average). Countries with a low level of income per capita are twice more exposed to a financial crisis than higher income level countries. 
2.2. Channelling financial disturbances though trade

Cavallo and Frankel (2008) find robust evidence that openness to trade reduces the vulnerability to crises. This is consistent with Martin and Rey's (2006) main conclusion about the effect of trade globalization on the likelihood of financial crashes: emerging markets showing increased financial integration without increased trade openness are at higher risk to financial disruptions. Similarly, trade integration can lead to fewer sudden stops in capital inflows according to Edwards (2004), thus leading to fewer output losses in more open economies.

The contrasting view, namely that trade propagates shocks, is presented by Abeysinghe and Forbes (2005). Fidrmuc and Korhonen (2010) point towards greater synchronisation of recession shocks in the presence of stronger trade ties. Haile and Pozo (2008) support this view in the case of currency crises. Feldkircher (2014) concludes from his empirical investigations that trade openness has amplified rather than mitigated the impact of the 2008 systemic banking crisis. His results suggest that the economic slump in the New Member States of the European Union has been fuelled essentially by the decline in their exports. Trade like non-trade barriers may have exacerbated durably the depressive impact of the systemic banking crisis on the real economy. All these empirical findings support the idea that the trade channel may act as transmitting stress globally.

Given these opposite views, one may better understand the disappointing results of Rose and Spiegel (2012) as concerns the contribution of foreign trade to the 2008 crisis. They specify international linkages in a macro-econometric model in order to identify the channels through which the US crisis might have spread its effects around the world. In particular, they find a negative relationship between export (or 
trade) dependence to the US economy and the country's exposure to financial disruptions. But the intensity of trade links does not help characterise to potential epicentres of the crisis.

Economic developments in the vulnerable economy prior to a crisis matter. This seems also to be the case of pre-crisis growth in its trading partners. The dynamism of domestic activity is heavily dependent on the health of foreign demand. According to Tsangarides (2012), a 1 per cent increase in the growth rate of foreign output implies a 2 per cent rise in GDP growth at home. Thus, international trade can foster the economic recovery in countries facing a currency crisis since foreign demand acts as a pull factor to domestic activity.

The trade channel may also interact with the choice for the currency regime to influence the dynamics leading to the crisis. It can do so by influencing private expectations, thus magnifying financial vulnerability when credibility on the authorities' commitment to the exchange rate parity vanishes. The currency regime may also influence the path to recovery because adjustment in the real exchange rate may be needed to improve price competitiveness in the export sector. Higher growth in tradable goods can foster output recovery. That said, there is still unconvincing empirical relevance about such a positive contribution of exchange rate flexibility during crisis times. On one hand, Tsangarides (2012) questions the stabilizing role of currency pegs compared with the performance of floating exchange rates during and following the Second Great Financial Crisis. Using a sample of fifty emerging market economies, he concludes to the limited role played by the exchange rate policy on macroeconomic performance during the crisis years (2007-2009). By contrast, the recovery has been worse for peggers than for floaters. However, 
Bussière et al. (2012) remain skeptical about any influence of exchange rate flexibility during the adjustment to a currency collapse.

\section{An extension to the Cerra-Saxena impulse response function approach}

The econometric approach is built to assess the impact of financial crises on potential output. To this end, we adapt the now popular method developed by Cerra and Saxena $(2005,2008)$. It has led to many empirical studies on the medium- to longrun consequences of currency, banking and/or sovereign debt crises by Abiad et al. (2011a, 2011b, 2013), Jorda et al. (2012), Bussière et al. (2012), Furceri and Mourougane (2012), Furceri and Zidzienicka (2012).

However, we depart from their original procedure in two important respects. First, we relax the rather strong assumption that imposes a uniform response of output growth in all the countries belonging to the same geographical region or sharing the same level of development to a crisis event. Such a common behaviour stems from the panel data model initially developed by Cerra and Saxena (2005). Instead, we allow all the slope parameters to differ from one country to another. Accounting for this potential source of heterogeneity allows for cross-country comparisons. Differences between distinct areas can then be studied through aggregation of statelevel impulses responses.

Second, we account explicitly for the fact that, once a shock occurred, the response of output growth in one country may spill over to its neighbours as a by-product of international trade linkages. By doing so, one is able to assess the importance of second round effects. Those may reflect the transmission of a shock due to strong 
dependencies across countries, as it could be during tranquil periods, and/or contagion in case of a financial crisis (Forbes, 2013).

Given these new features, our econometric methodology is made of two important steps. First of all, we estimate a univariate autoregressive growth equation and derive the relative impulse response functions:

$g_{i, t}=\alpha_{i}+\lambda_{i} t+\sum_{p=0}^{4} \beta_{i, p} \quad g_{i, t-p}+\sum_{q=0}^{4} \gamma_{i, q} g_{i, t-q}^{\text {partners }}+\sum_{r=0}^{4} \delta_{i, r} D_{i, t-r}+u_{i, t}$

Like Cerra and Saxena (2008), we define $g_{i, t}$ as the growth rate of the industrial production index in month $t$ in country $i$ (used as a proxy of domestic activity). $D_{i, t-r}$ is a dummy variable which is equal to 1 at the crisis event or a financial crisis in country $i$ in month $t-r$, and 0 otherwise. We also follow past studies by setting the maximum lag order to 4 (months here). The constant term $\alpha_{i}$ corresponds to the fixed effect specific to country $i$, while $t$ is a deterministic trend.

A first original feature here is that the direct influence of the financial crisis on the output dynamics - given by the $\delta_{i, r}$ parameters in Equation (1) $r$ months ahead in country $i$ - may vary from one economy to another. This is a less stringent condition than the one imposed initially by Cerra and Saxena $(2005,2008)$.

The second novelty from formula (1) is the explicit account of a possible transmission channel of the financial crisis through the output growth of country's $i$ trading partners. This indirect effect is captured through the sequence of terms $g_{i, t-q}^{\text {partners }}$ for country $i$ up to four months in the past from the current month $t$. The variable $g_{i, t-q}^{\text {partners }}$ is the sum of growth rates weighted by export shares. For any given month $t$ and any country $i$, we then define an additional set of macro-economic identities as: 


$$
g_{i, t}^{\text {partners }} \equiv \sum_{\substack{k=1 \\ k \neq i}}^{N} \omega_{i, k, t} g_{k, t}
$$

$N$ is the total number of countries in the sample. The weight coefficients $\omega_{i, k, t}$ measure the share of trade of country $i$ with its partner $k$ in the total foreign trade of country $i$ in month $t$. Adding this term into the regression Equation (1) has severe implications since the error terms $u_{i, t}$ are likely to be correlated. We rely on the Seemingly Unrelated Regression Estimator (SURE) to deal with the endogeneity issue in the system resulting from Equation (1).

Next, we build IRF to two kinds of shocks. The first one is an adverse demand shock specific to a given country $i$ that materializes in a (minus) one-standard deviation realization of the error term $u_{i, t}$. The second one corresponds to the Global Financial Crisis in 2008. We follow Gourinchas and Obstfeld (2012) by assuming that all countries in our sample were hit by that systemic banking crisis. There is however no consensus about the dating of this big financial crisis since the Lehman Brothers' failure occurred several months after speculative pressures surged on the US subprime market. We thus assume that each crisis dummy $D_{i}$ takes the value one for every months of year 2008. This is in line with previous studies based on annual data like Cerra and Saxena (2008).

The shape of these response functions in country $i$ depends on the set of the estimated $\lambda_{i}, \beta_{i}$, and $\delta_{i}$ coefficients in Equation (1). These are the coefficients associated with the trend, the lagged values of potential output growth and those of the financial crisis dummy, respectively. To get a 95\% confidence interval, we run 5,000 Monte Carlo simulations under each scenario using critical values from the 
standard Gaussian limiting distribution. It is illustrated by the dashed lines around the mean (cumulative) response in Figures 1 to 4 in the appendix.

The resulting system from Equation (1) is estimated on a balanced panel of monthly OECD data from 1993:01 to 2013:06. Due to limited data availability on monthly bilateral trade relationships, our sample covers 26 OECD and non-OECD economies, including: Argentina, Australia, Austria, Belgium (together with Luxemburg), Canada, the Czech Republic, Denmark, Finland, France, Germany, Greece, Hungary, Ireland, Italy, Japan, Mexico, the Netherlands, Norway, Poland, Portugal, Spain, Sweden, Turkey, the United Kingdom, and the United States. As said above, we wish to make comparisons between countries given their geographical situations and their degrees of development. Because we focus on the role played by the intensity of cross-country trade linkages, we also wish to assess the influence of the regional trade and/or monetary agreements on the output responses to negative shocks, originating either over the business cycle or from distress in the banking system. To our knowledge, such an appraisal is new to the literature.

\section{The mixed impact of international trade during the 2008 crisis}

Domestic shocks and international trade relationships

Impulse-response functions of a $1 \%$ demand shock in a country $i$ are simulated according to two scenarios. In the first one, trade spillover effects are disregarded so that the $g_{i, t-q}^{\text {partners }}$ variables do not appear in Equation (1) above. In other terms, all the parameters $\gamma_{i, q}$ are set to 0 (there is no trade effects). It corresponds to our benchmark case similar to the one initially considered by Cerra and Saxena (2005, 
2008). In the second situation, we account explicitly for trade spillover effects through the $\gamma_{i, q}$ parameters in the Equation (1).

Table 1 gives the cumulative impact of a negative demand shock 18 months after its occurrence in both scenarios. The last column shows that trade magnifies the effects of shocks from 1.3\% (for a shock in Australia) to 700\% (for a shock in Germany). Trade effects are higher when the shock hits a large country: it amounts to roughly $520 \%$ in the United States and $330 \%$ in France while it is only $7 \%$ in Norway and $10 \%$ in Greece (Australia is however an exception). The corresponding Figure 1 in the appendix depicts the whole path of the weighted average output growth in various areas.

Table 1 shows a strong and positive relationship between openness and contagion effects: spillover effects after a demand shock are larger for the main exporting countries. This result is consistent with Abeysinghe and Forbes (2005). The effect captured also encompasses the policy reaction triggered by the crisis and its consequences on the real economy. However, it is not easy to disentangle the pure crisis effect from the policy response, given the absence of a counterfactual. Considering now the trade channel, the time-path of the cumulative impact of a domestic demand shock on economic growth is illustrated in Figure 2 (in appendix). Unlike the Figure 1, IRF reported in Figure 2 are computed from Equation 1 with the inclusion of the $g_{i, t-q}^{\text {partners }}$ terms under a set of constraints given by the corresponding foreign growth identities. The corresponding graphs show that the advanced economies in our sample behave quite differently from the emerging market economies. In this latter group, the cumulative response of output to a negative demand shock is significantly negative during the first three months only. By contrast, output loss is more persistent in the advanced countries. 
Table 1. Cumulated responses of output growth to a negative domestic demand shock during tranquil times (18 month horizon)

\begin{tabular}{lccc} 
Country & Without trade, in \% & With trade, in \% & Trade effect, in \% \\
& $(1)$ & $(2)$ & $(2)$ \\
\hline Argentina & -3.4 & -4.0 & 16.0 \\
Australia & -1.3 & -1.3 & 1.4 \\
Austria & -0.7 & -1.4 & 104.9 \\
Belgium-Luxemburg & -0.8 & -2.6 & 230.1 \\
Canada & -0.8 & -2.2 & 188.7 \\
Czech Republic & -1.2 & -2.1 & 80.4 \\
Denmark & -1.3 & -1.9 & 43.3 \\
Finland & -1.0 & -1.5 & 41.3 \\
France & -0.4 & -1.8 & 328.3 \\
Germany & -0.7 & -5.3 & 698.5 \\
Greece & -1.0 & -1.1 & 9.5 \\
Hungary & -0.9 & -1.6 & 74.1 \\
Ireland & -2.3 & -3.2 & 41.2 \\
Italia & -0.7 & -2.4 & 241.1 \\
Japan & -1.4 & -4.0 & 185.4 \\
Mexico & -0.9 & -2.0 & 111.5 \\
Netherlands & -1.0 & -2.7 & 184.0 \\
Norway & -1.1 & -1.2 & 7.1 \\
Poland & -1.4 & -2.5 & 80.6 \\
Portugal & -1.0 & -1.3 & 26.1 \\
Spain & -0.7 & -1.5 & 133.3 \\
Sweden & -0.9 & -1.7 & 91.8 \\
Turkey & -1.9 & -3.2 & 72.4 \\
United Kingdom & -0.4 & -1.0 & 153.1 \\
United States & -0.6 & -3.6 & 522.1 \\
\hline & & &
\end{tabular}

Figure 2 also reveals differences among currency and trade unions. The instantaneous impact is the strongest for the euro area, but the cumulative output loss is the highest within NAFTA at a longer (18-month) horizon. In comparison with Figure 1, a negative demand shock has a deeper impact on industrial production when trade relationships are accounted for. This is particularly the case for the euro area. 
The 2008 Global Financial Crisis and trade spillovers

In order to replicate the 2008 financial crisis, we simulate a systemic banking crisis: all countries are affected by a banking crisis during one year. The methodology is the same as before: IRF to a banking crisis are simulated i) without trade contagion that is as if exports of the country $i$ were null and ii) with trade contagion so that IRF take into account the reaction of output growth abroad through the set of variables $g_{i, t-q}^{\text {partners }}$

Like Table 1, Table 2 below reports the total impact on output growth at the country level 18 months after the worldwide systemic event occurred. Figures 3 and 4 in the appendix illustrate the whole trajectories over this horizon whether spillover effects through international trade are taken into account or not.

In the first column of Table 2, most of countries tend to react negatively to a banking crisis. If these countries are allowed to exports, the multipliers tend to decrease in absolute value (column 2). In this case, trade dampens the negative effects of a banking crisis. Countries that react positively to the banking crisis (Australia, Canada, Ireland, Norway, Poland and the United States) have lower multipliers when they are allowed to exports. Again, trade dampens the effects of a systemic banking crisis. The only exception is Poland. The unusual post-crisis macroeconomic performance of Poland is well documented (OECD, 2012 and Sobják, 2013). Poland's economic growth was much less harmed by the Great Financial Crisis given its low degree of openness to trade, its high trade diversification, the sustained growth of domestic consumption and public investment. All these specific factors 
may explain the positive impact of trade in the Polish economy during the aftermath of the 2008 crisis.

Table 2. Cumulated responses of output growth to the 2008 Global Financial Crisis (18 month horizon)

\begin{tabular}{|c|c|c|c|}
\hline Country & $\begin{array}{l}\text { Without trade, in \% } \\
\text { (1) }\end{array}$ & $\begin{array}{l}\text { With trade, in } \% \\
\text { (2) }\end{array}$ & $\begin{array}{c}\text { Trade effect, in \% } \\
(2) /(1)\end{array}$ \\
\hline Argentina & -9.4 & -2.9 & -69.5 \\
\hline Australia & 0.7 & -2.8 & -480.6 \\
\hline Austria & -7.6 & -0.5 & -93.6 \\
\hline Belgium-Luxemburg & -11.9 & -8.2 & -30.7 \\
\hline Canada & 0.4 & -0.3 & -172.3 \\
\hline Czech Republic & -14.5 & -6.4 & -55.9 \\
\hline Denmark & -5.2 & 0.1 & -101.6 \\
\hline Finland & -23.3 & 0.2 & -100.7 \\
\hline France & -9.0 & -1.3 & -85.9 \\
\hline Germany & -17.3 & -4.9 & -71.5 \\
\hline Greece & -3.2 & -3.3 & 1.1 \\
\hline Hungary & -17.9 & -5.5 & -68.9 \\
\hline Ireland & 4.1 & -1.5 & -136.1 \\
\hline Italia & -19.7 & -2.6 & -86.8 \\
\hline Japan & -22.8 & -1.3 & -94.2 \\
\hline Mexico & -17.1 & -0.3 & -97.9 \\
\hline Netherlands & -12.6 & -4.5 & -64.3 \\
\hline Norway & 8.0 & 6.2 & -21.9 \\
\hline Poland & 3.2 & 5.1 & 59.5 \\
\hline Portugal & -3.3 & -1.2 & -64.7 \\
\hline Spain & -12.0 & -2.5 & -79.3 \\
\hline Sweden & -11.3 & -1.5 & -86.4 \\
\hline Turkey & -8.0 & -7.4 & -7.0 \\
\hline United Kingdom & -1.6 & 0.0 & -97.2 \\
\hline United States & 1.7 & -0.4 & -125.8 \\
\hline
\end{tabular}

Another interesting feature concerns the influence of regional integration and the stage of development of the countries under study. This is illustrated in Table 3 (see also Fig. 1 to 4 for the corresponding dynamics). We consider three distinct 
economic regions of the world ${ }^{1}$ : the euro area with all its founding Member States (including Greece), the 6 remaining Members States of the European Union which have not joined the euro yet, and the 3 countries participating to the North American Free Trade Area. We also distinguish the impact of trade between two groups of advanced and developing countries according to the World Bank classification.

Table 3. Regional patterns of trade spillover effects on output growth given type of shock (weighted average of countries responses by their GDP shares)

\begin{tabular}{lrr} 
Country group & Demand shock & 2008 Global Crisis \\
\hline World-26 & 260.2 & -75.2 \\
Euro-12 & 292.1 & -69.9 \\
Others EU-7 & 252.6 & -59.7 \\
NAFTA-3 & 433.7 & -126.8 \\
Rest of World-4 & 109.1 & -130.1 \\
& & \\
Advanced-19 & 316.7 & -125.4 \\
Developing-7 & 63.0 & -38.9 \\
\hline
\end{tabular}

Table 3 shows significant heterogeneity in the trade spillover effect on output growth across regional trade agreements. Its magnitude varies from 1 to 4 times in the case of a domestic shock when there is no financial crisis (see column 2). By contrast, there is less variability following the 2008 Global Financial Crisis (see column 3).

The level of per capita GDP has a strong influence on the magnitude of the output growth response to a domestic shock during tranquil (or non-crisis) periods. The trade multiplying effect is 5 times greater in the group of advanced countries than in

${ }^{1}$ Euro-12: Germany, Austria, Belgium-Luxembourg, Spain, Finland, France, Greece, Ireland, Italy, Netherlands, Portugal. Others EU-7: Denmark, Hungary, Norway, Poland, United Kingdom, Sweden, Czech Republic. NAFTA-3: Canada, Mexico, USA. Rest of World-4: Australia, Japan, Turkey, Argentina. Developing-7: Greece, Hungary, Mexico, Poland, Czech-Republic, Turkey, Argentina. 
the developing world. Instead, the 2008 Global Financial Crisis shows no sign of such discrepancies. This is broadly consistent with the better resilience of the developing economies to the systemic banking crisis that originated in the US (see Gourinchas and Obstfeld, 2012, among others). When comparing Figure 3 with Figure 4, the absence of a trade collapse would have helped to mitigate the recession following the 2008 crisis. This is particularly the case in the euro area and the emerging economies, while the trade channel is less convincing within NAFTA.

\section{Conclusion}

Using the methodology of Cerra and Saxena (2008), we simulate the impact of the 2008 banking crisis on growth developments for 26 countries from 1996 to 2013. However, Cerra and Saxena do not take into account globalization effects. In this paper, we integrate trade relationships in order to decompose between directs effects from shocks and indirect effects from trade. Trade contagion is simulated in the context of, first a demand shock and then of systemic banking crisis. Trade contagion is important in both cases. But, with a demand shock, contagion effects of trade are positive and correlated with the size and the openness of the country. Results are in line in those of Abeysinghe and Forbes (2005). However, according to Edwards (2004), Martin and Rey (2006) and Cavallo and Frankel (2008), trade globalization reduces effects of financial crisis.

Finally, our results show that trade contributes more to extend demand shock $(260 \%$ in average) than to reduce financial crisis (-75\%). 


\section{References}

Abeysinghe, T. and Forbes, K. (2005), Trade linkages and output-multiplier effects: a structural VAR approach with a focus on Asia, Review of International Economics, $13,356-375$.

Abiad, A., Dell'Ariccia, G. and Li, B. (2011a), Credit less recoveries, IMF Working Papers, WP/11/58, International Monetary Fund.

Abiad, A., Furceri, D., Kalemli-Ozcan, S. and Pescatori, A. (2013) Dancing together? Spillovers, common shocks, and the role of financial and trade linkages, World Economic Outlook, chapter 3, International Monetary Fund, October, 103138.

Abiad, A., Mishra, P. and Topalova, P. (2011b), How does trade evolve in the aftermath of the financial crisis? IMF Working Papers, No. 11/3, International Monetary Fund.

Amity, M. and Weinstein, D. (2011), Exports and financial crises, Quarterly Journal of Economics, 126, 1841-1877.

Baldwin, R. and Taglioni D. (2009), The Great Trade Collapse: What Caused It and What Does It Mean. Centre for Economic Policy Research and VoxEu.org, London. Berman N., De Sousa J., Martin P. and Mayer T. (2013), Time to ship during financial crises, NBER International Seminar on Macroeconomics, University of Chicago Press, 9(1), 225-260.

Borensztein, E. and Panizza, U. (2010), Do sovereign defaults hurt exporters?, Open Economies Review, 21(3), 393-412. 
Bricongne, J.-C., Fontagné, L., Gaulier, G., Taglioni, D. and Vicard, V. (2012), Firms and the global crisis: French exports in the turmoil, Journal of International Economics, 87(1), 134-146.

Bussière, M., Saxena, S. and Tovar, C. (2012), Chronicle of currency collapses: Reexamining the effects on output, Journal of International Money and Finance, 31, 680-708.

Campa, J. (2004), Exchange rates and trade: How important is hysteresis in trade?, European Economic Review, 48(3), 527-548.

Cavallo, E. and Frankel, J. (2008), Does openness to trade make countries more vulnerable to sudden stops, or less? Using gravity to establish causality, Journal of International Money and Finance, 27(8), 1430-1452.

Cerra, V. and Saxena, S. (2005), Did output recover from the Asian crisis?, IMF Staff Papers, 52, 1-23.

Cerra, V. and Saxena, S. (2008), Growth dynamics: The myth of economic recovery, American Economic Review, 98, 439-457.

Chor, D. and Manova, K. (2012), Off the cliff and back? Credit conditions and international trade during the global financial crisis, Journal of International Economics, 87(1), 117-133.

Edwards, S. (2004), Financial openness, sudden stops and current account reversals, American Economic Review, 94(2), 59-64.

Feldkircher, M. (2014), The determinants of vulnerability to the global financial crisis 2008 to 2009: Credit growth and other sources of risk, Journal of International Money and Finance, 43, 19-49. 
Fidrmuc, J. and Korhonen, I. (2010), The impact of the global financial crisis on business cycles in Asian emerging economies, Journal of Asian Economics, 21(3), 293-303.

Forbes, K. (2013), The big “C”: Identifying and mitigating contagion, in Federal Reserve Bank of Kansas City (ed.), The Changing Policy Landscape, pp. 23-87.

Furceri, D. and Mourougane, A. (2012), The effect of financial crises on potential output: New empirical evidence from OECD countries, Journal of Macroeconomics, 34, 726-742.

Furceri, D. and Zdzienicka, A. (2012), How costly are debt crises? Journal of International Money and Finance, 31, 726-742.

Gourinchas, P.-O. and Obstfeld, M. (2012), Stories of the twentieth century for the twenty-first, American Economic Journal: Macroeconomics, 4, 226-265.

Haile, F. and Pozo, S. (2008), Currency crisis contagion and the identification of transmission channels, International Review of Economics \& Finance, 17(4), 572588.

Imbs, J. (2010), The First Global Recession in Decades, IMF Economic Review, 58(2), 327-354.

Jordà, O., Schularick, M. and Taylor, A. M. (2012), Credit booms gone bust: Monetary policy, leverage cycles and financial crises, 1870-2008, American Economic Review 102, 1029-1061.

Love, I., Preve, L. and Sarria-Allende, V. (2007), Trade credit and bank credit: Evidence from recent financial crises, Journal of Financial Economics, 83(2), 453469. 
Manova, K., Wei, S.-W. and Zhang, Z. (2011), Firm exports and multinational activity under credit constraints, NBER Working Papers, $\mathrm{n}^{\circ} 16905$, National Bureau of Economic Research.

Martin, P. and Rey, H. (2006), Globalization and emerging markets: With or without crash?, American Economic Review, 96(5), 1631-1651.

Ng, S. and Wright, J. (2013), Facts and challenges from the Great Recession for forecasting and macroeconomic modeling, Journal of Economic Literature, 51(4), $1120-1154$.

OECD (2012), Poland, Economic Surveys, Organization for Economic Cooperation and Developement, March.

Rajan, R. and Zingales, L. (1998), Financial dependence and growth, American Economic Review, 88(3), 559-86.

Reinhart, C. and Rogoff, K. (2009), The aftermath of financial crises, American Economic Review, Papers and Proceedings, 99, 466-472.

Reinhart, C. and Rogoff, K. (2014), Recovery from financial crises: Evidence from 100 episodes, American Economic Review, Papers and Proceedings, 104(5), 50-55.

Rose, A. and Spiegel, M. (2012), Cross-country causes and consequences of the 2008 Crisis: Early warning, Japan and the World Economy, 24, 1-16.

Sobják, A. (2013), From the Periphery to the Core? Central Europe and the Economic Crisis, PISM Policy Paper, 55.

Tsangarides, C. (2012), Crisis and recovery: Role of the exchange rate regime in emerging market countries, Journal of Macroeconomics, 34, 470-488. 
Fig. 1. Cumulative mean impulse response of output growth to a domestic demand shock without trade spillovers ( $95 \%$ confidence band)
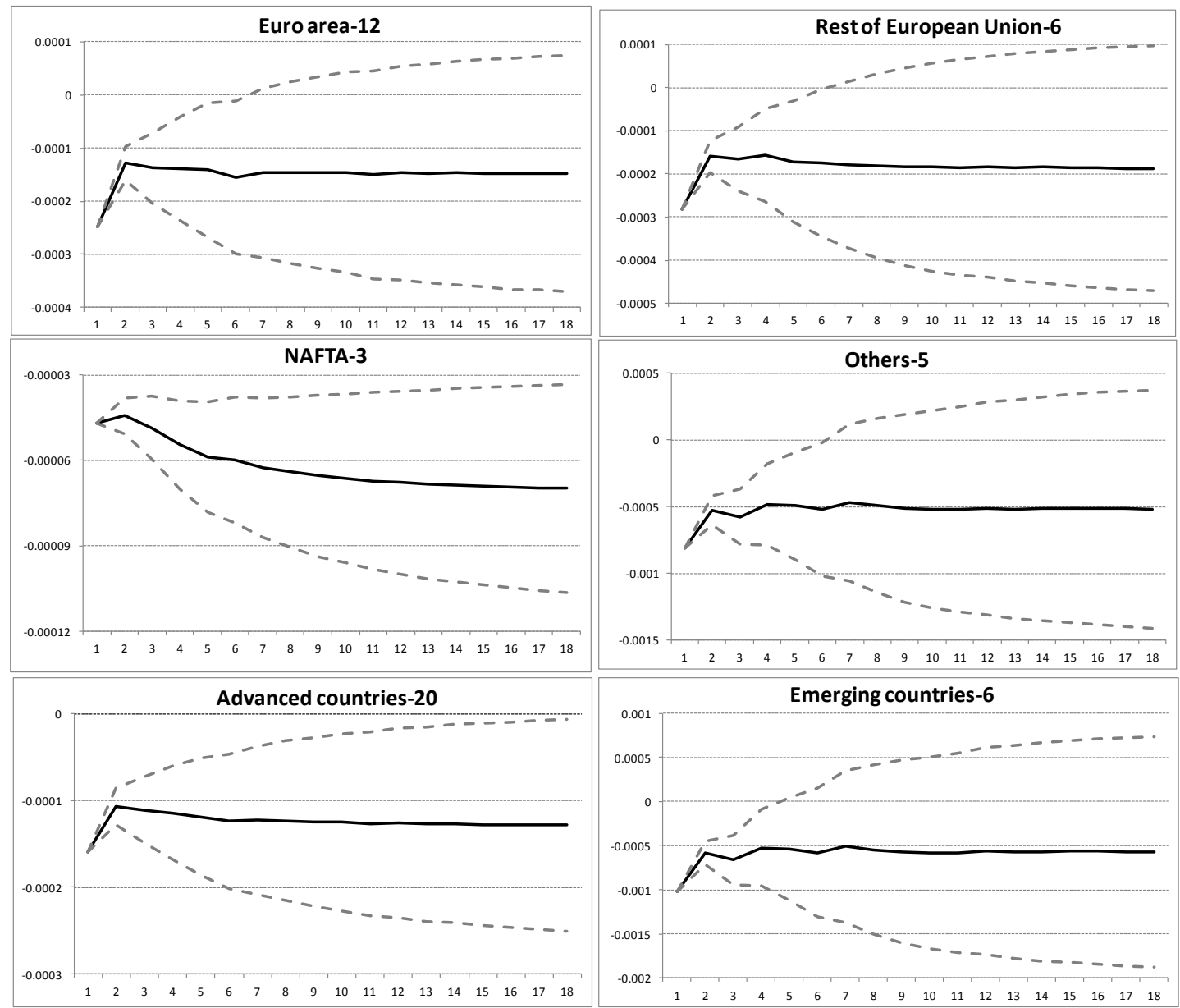
Fig. 2. Cumulative mean impulse response of output growth to a domestic demand shock with trade spillovers ( $95 \%$ confidence band)
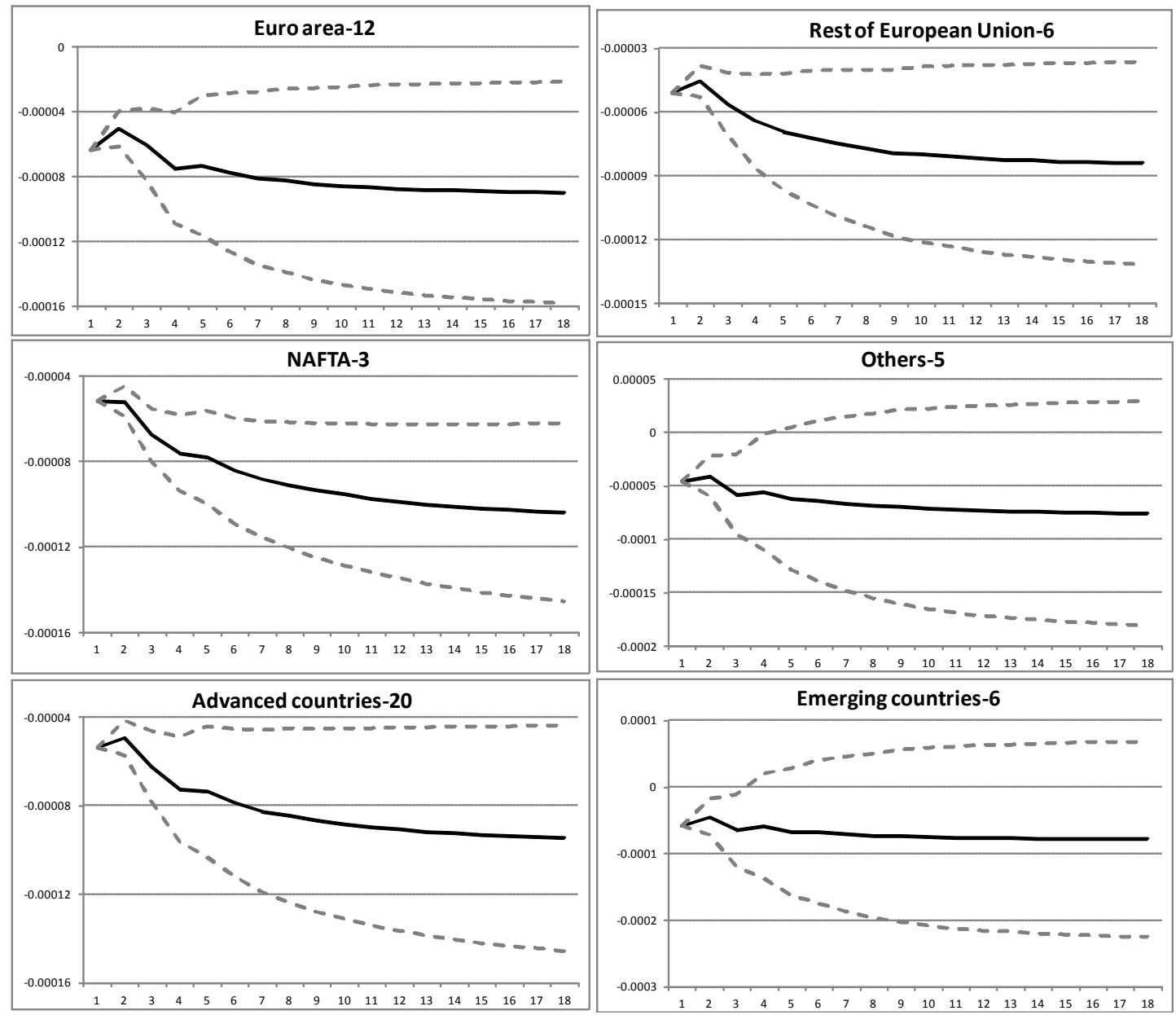
Fig. 3. Cumulative mean impulse response of output growth to the 2008 Global Financial Crisis without trade spillovers (95\% confidence band)
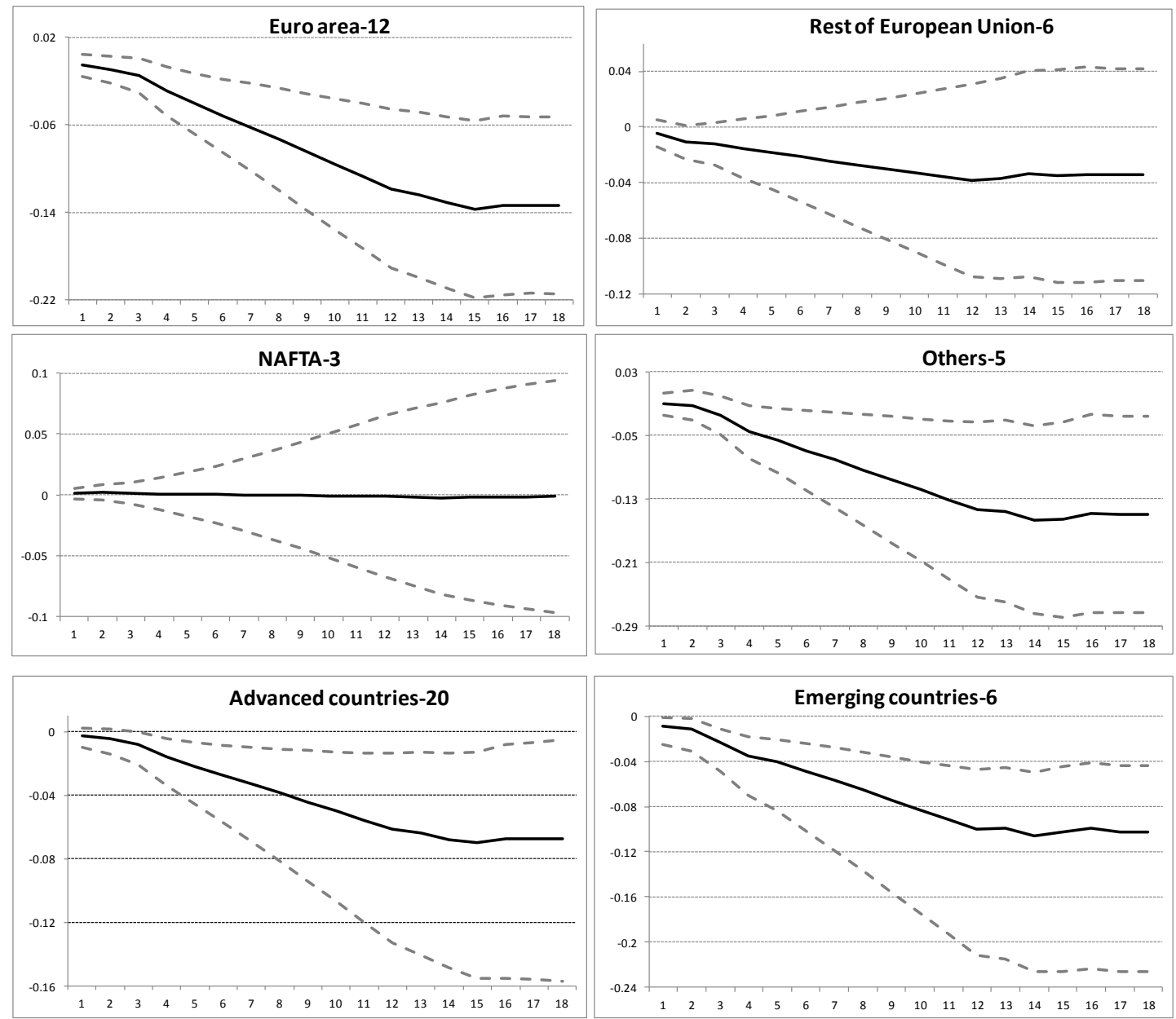
Fig. 4. Cumulative mean impulse response of output growth to the 2008 Global Financial Crisis with trade spillovers (95\% confidence band)
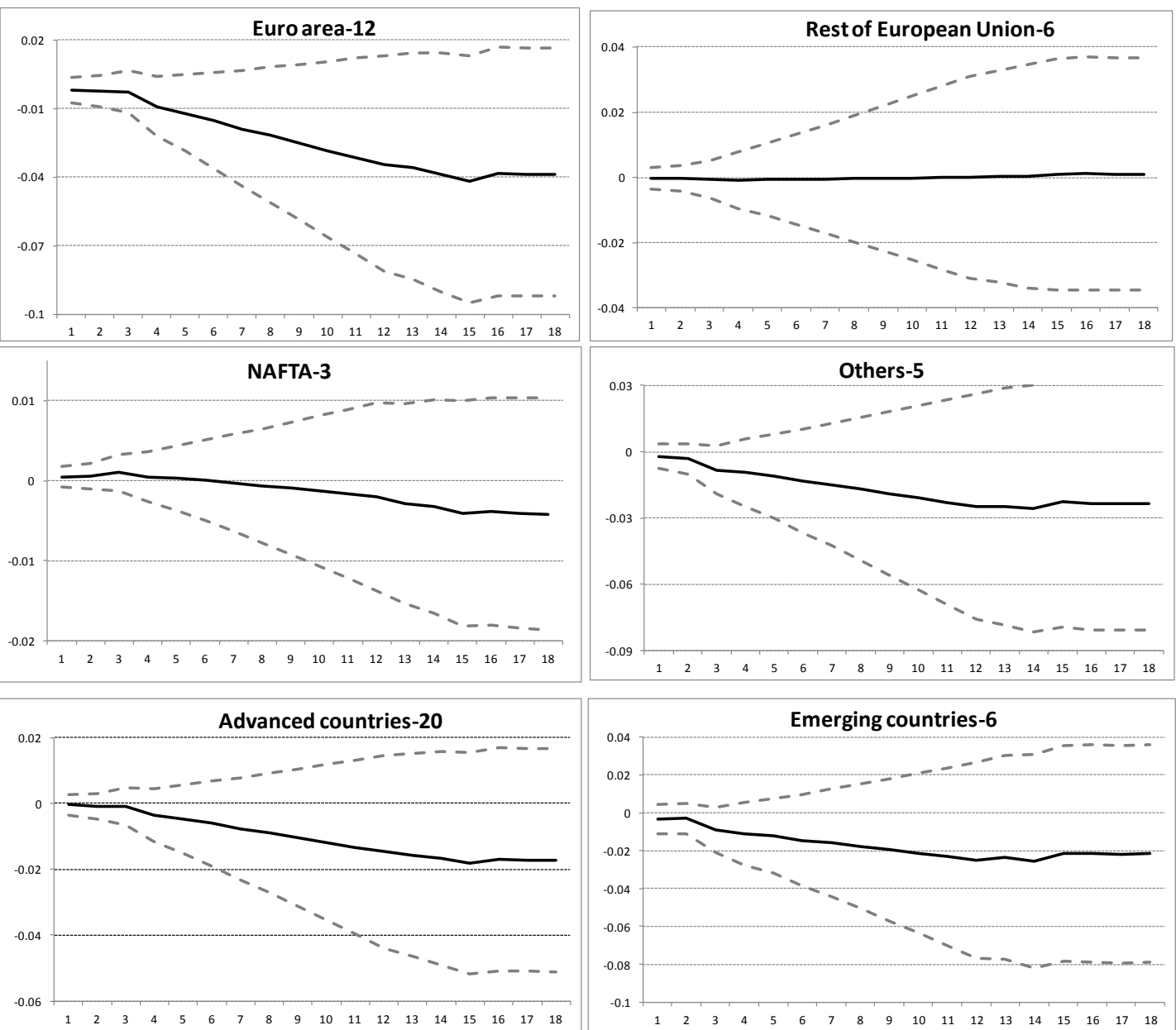